\title{
Effect of Boron Supplement on Yield of Wheat Grown in Calcareous Soils of Different Textural Classes under Arid Conditions
}

\author{
Baydaa H. A. Al-Ameri ${ }^{1}$, Suad A. Al-Saedi ${ }^{1}$ \& Ibrahim B. Razaq ${ }^{1}$ \\ 1 Soil \& Water Resources Research Center, Agriculture Research Directorate, Ministry of Science and \\ Technology, Baghdad, Iraq \\ Correspondence: Baydaa H. A. Al-Ameri, Soil \& Water Resources Research Center, Agriculture Research \\ Directorate, Ministry of Science and Technology, Baghdad, Iraq. E-mail: Baydaa.2012@yahoo.com
}

Received: September 16, 2018

Accepted: October 17, $2018 \quad$ Online Published: December 15, 2018

doi:10.5539/jas.v11n1p112

URL: https://doi.org/10.5539/jas.v11n1p112

\begin{abstract}
Boron sufficiency supply to plant in calcareous soils of arid regions is severely reduced under arid climatic conditions. Therefore, this study was conducted to determine the effect of Boron (B) fertilization on yield of

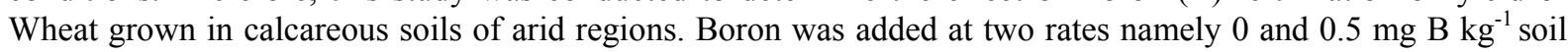
to three most common textured class's soils. Straw and grain yield was determined on oven dried basis. B content of plants was determined as well. Straw and grain yield of wheat was significantly increased by (67.0 and $87.1 \%),(24.5$ and $82 \%)$ and $(64.5$ and $48 \%)$ under the addition of $0.5 \mathrm{mg} \mathrm{B} \mathrm{Kg}^{-1}$ soil over that of no B addition to clay, loam and sandy loam soil, respectively. Results also showed that wheat grown on the coarse-textured soil had the least B uptake per pot compared to loam and clay textured soils. B content in straw and grain was increased by (77.4 and 121\%), (81.2 and 157\%) and (184 and 96.9\%) under B addition compared to those of zero B addition to clay soil, loam soil and sandy loamy soil, respectively. Response to B addition, significantly, increased in all soils due to increase of available B content in soils which may suggest the importance of adding adequate rate of $\mathrm{B}$ application under cropping system of arid regions.
\end{abstract}

Keywords: Boron uptake, dry mater, nutrients, response to boron

\section{Introduction}

Boron (B) is a necessary element for plants growth and development (Muntean, 2009). Its deficiency has been realized as the second most important micronutrient constraint in crops after that of zinc $(\mathrm{Zn})$ on global scale (Ahmed et al., 2009). It is required by plants in many metabolic processes, including plasma membrane stability, cell wall strength, nucleic acid metabolism, cell division, plant hormone synthesis, fruit and seed development, sugar synthesis, and transport (Brown et al., 2002; Bassil \& Brown, 2004; De Oliveira et al., 2006).

The factors affecting $\mathrm{B}$ uptake include soil texture, $\mathrm{pH}$, lime content, soil moisture content (Gupta \& Hitesh, 2013). Boron deficiency and toxicity symptoms in plants is in the range of 0.028 to $0.093 \mathrm{mmol} / \mathrm{L}$ for sensitive crops and 0.37 to $1.39 \mathrm{mmol} / \mathrm{L}$ for tolerant crops (Goldberg, 1997).

Boron is relatively immobile in plant, and thus its availability is essential at all stages of growth, especially during maturity development. The deficiency of B has been reported to result in considerable yield reduction in various crops, like cereals (rice, corn, wheat), legume, oilseed and fruit trees (Sinha et al., 1991; Borkakati \& Takkar, 2000; Niaz et al., 2007; Rashid et al., 2005; Johnson et al., 2005; Zia et al., 2006). Rashid 2006, on the other hand, found that B fertilizer increased the yield of B-deficient crops.

Boron bioavailability decreases under drought condition because of reduced mobility of B from soil by mass flow to roots (Diana, 2006; Chang, 1993; Barber, 1995). Boron can move relatively long distances by mass flow and diffusion to roots. Soil drying reduces B diffusion by reducing the mobility of soil solution and increasing the diffusion path length (Hajiboland \& Farhanghi, 2011).

Raza et al. (2002) and Malhi et al. (2003) reported that coarse-textured soils contain less available B than fine-textured soils. Furthermore, surface area of soil clay minerals, calcium carbonate, aluminum and iron oxides and organic matter, are the primary B adsorbing surfaces in soils (Goldberg, 1997). The level of native B is also closely related to the clay content of the soil (Elrashidi \& O’Connor, 1982; Raza et al., 2002). 
The level of B adsorbed by the soil thus largely depends on soil texture in addition to $\mathrm{pH}$ of soil solution. It increases with an increase in clay content (Elrashidi \& O'Connor, 1982).

Shortages of B in wheat cultivated soils have been observed in various arid and semi-arid regions. Therefore, this study was conducted to assess Wheat response to B fertilization in calcareous soils of arid region in Iraq.

\section{Materials and Methods}

Three alluvial soils (Typic Torrifluvents) (Soil Taxonomy, 1975) of Caly, Loam and Sandy loam textured were selected for this study. Soil samples were obtained from Ap surface horizon at 0-30 cm depth. Samples were air dried and grounded to pass $2.0 \mathrm{~mm}$ sieve. Physical and chemical properties of the soil were determined (Table $1)$.

Table 1. Characteristics of soils used

\begin{tabular}{|c|c|c|c|}
\hline \multirow{2}{*}{ Character } & \multicolumn{3}{|c|}{ soils } \\
\hline & Clay & Loam & Sandy loam \\
\hline Sand $\left(\mathrm{gm} \mathrm{kg}^{-1}\right)$ & 162.63 & 428.7 & 755.53 \\
\hline Silt $\left(\mathrm{gm} \mathrm{kg}^{-1}\right)$ & 378.03 & 368.7 & 80.16 \\
\hline Clay $\left(\mathrm{gm} \mathrm{kg}^{-1}\right)$ & 459.33 & 202.6 & 164.33 \\
\hline Texture & Clay & Loam & Sandy loam \\
\hline EC $1: 1\left(\mathrm{dSm}^{-1}\right)$ & 0.72 & 0.74 & 0.16 \\
\hline pH 1:1 & 7.50 & 6.82 & 7.69 \\
\hline Calcium carbonite $\left(\mathrm{g} \mathrm{kg}^{-1}\right.$ soil $)$ & 238.3 & 250.0 & 256.0 \\
\hline Organic mater ( $\mathrm{g} \mathrm{kg}^{-1}$ soil) & 20.0 & 19.8 & 10.0 \\
\hline NH4- N (mg N Kg ${ }^{-1}$ soil) & 40.88 & 30.92 & 12.32 \\
\hline NO3- N (mg N Kg ${ }^{-1}$ soil) & 14.7 & 10.42 & 7.7 \\
\hline Available-P (mg Kg ${ }^{-1}$ soil) & 18.21 & 23.51 & 13.29 \\
\hline Available-Ca $\left(\mathrm{C}\right.$ mole $+\mathrm{kg}^{-1}$ soil $)$ & 74.49 & 81.425 & 46.52 \\
\hline Available- $\mathrm{Mg}\left(\mathrm{C}\right.$ mole $+\mathrm{kg}^{-1}$ soil $)$ & 5.48 & 5.95 & 2.80 \\
\hline Available-K (C mole $+\mathrm{kg}^{-1}$ soil $)$ & 7.58 & 9.83 & 2.16 \\
\hline Available- $\mathrm{Na}\left(\mathrm{C}\right.$ mole $+\mathrm{kg}^{-1}$ soil $)$ & 867.78 & 863.98 & 71.65 \\
\hline Boron (H.W) $\mathrm{mg} \mathrm{Kg}^{-1}$ soil & 3.050 & 1.268 & 0.147 \\
\hline
\end{tabular}

Pot experiment was conducted as Randomized Complete Block Design in a three replicates. Boron was added in two rate of application namely, $0.0 \mathrm{mg} \mathrm{B} \mathrm{Kg}^{-1}$ soil and $0.5 \mathrm{mg} \mathrm{B} \mathrm{Kg}^{-1}$ soil. Therefore, the experiment includes total of six treatments. The treatments were arranged in three replicates. In order to achieve the objective. Plastic pots of $7000 \mathrm{gm}$ were used for growing wheat under greenhouse conditions. Three hundred gram of washed fine gravel were placed at the bottom of each pot and covered with $200 \mathrm{~g}$ of pure sand washed previously with $0.01 \mathrm{M}$ hydrochloric acid and distilled water. Weights of $5000 \mathrm{~g}$ of each soil were transferred to the pots. Boron fertilizer was added in a Liquid form at a layer of $2 \mathrm{~cm}$ depth of the soil. Pots were then seeded to 12 seeds of wheat. The seedlings were then thinned to 7 seedlings per pot after 3 days of emergency. Soil moisture in all pots was maintained at $75 \%$ of field capacity. Macro nutrients of N, P and K were added to pots at a level of 100, 50 and $63 \mathrm{mg} \mathrm{kg}^{-1}$, respectively.

At maturity (after 150 days of planting) plants were harvested. Grain and straw yield of wheat of each pot was dried at $65^{\circ} \mathrm{C}$ in an oven until weight is stable. Grain and straw was determined as well as the weight of 100 seed. The dried grains were grilled and ash drying digested according to Page et al. (1982). B was measured with ICP (Inductivity Couple Plasma Atomic Emission Spectrometer model ICPE-9000 SHIMADZU).

\section{Results and Discussion}

\subsection{Dry Mater Yield}

\subsubsection{Straw Yield}

Results (Table 2) showed that straw yield of wheat, upon addition of B at a level of $0.5 \mathrm{mg}$ per $\mathrm{Kg}$ soil, increased by $67.0 \%, 24.5 \%$ and $64.5 \%$ over that of no Boron addition to clay, loam and sandy loam soil, respectively (Huang et al., 2000). High response to B addition in clay textured soil may be attributed to adequate levels of plant essential nutrients (Table 1) in this soil and the possibility that B is the main constrain for plant growth in 
heavy textured soil, which is in agreement with the report of (Shorrocks, 1997). Weight of yield of straw per pot with and without $\mathrm{B}$ addition was significantly the highest under the clay textured soil and was the significantly least under the sandy loam textured soil which is in agreement with plant essential nutrient of the two soils. This may clearly indicate that other plant growth limiting factor other than B is prevailing in such soils (Niaz et al., 2002; Niaz et al., 2007).

Table 2. Effect of B application on straw yield

\begin{tabular}{|c|c|c|c|c|}
\hline \multirow{2}{*}{ Application level } & Clay soil & Loam soil & Sandy loamy soil & Mean $\left(\mathrm{X}^{-}\right)$ \\
\hline & \multicolumn{4}{|c|}{ Straw yield gm pots ${ }^{-1}$} \\
\hline 0.0 & 21.03 & 19.33 & 14.03 & 18.13 \\
\hline 0.5 & 35.13 & 24.07 & 23.13 & 27.44 \\
\hline Mean $\left(\mathrm{X}^{-}\right)$ & 28.08 & 21.7 & 18.58 & 22.787 \\
\hline \multirow{2}{*}{ Variable } & \multicolumn{4}{|c|}{ Least Significant Difference LSD } \\
\hline & \multicolumn{4}{|c|}{ Straw yield gm pot ${ }^{-1}$} \\
\hline Application level & \multicolumn{4}{|c|}{1.498} \\
\hline Soil & \multicolumn{4}{|c|}{1.834} \\
\hline Interaction & \multicolumn{4}{|c|}{2.594} \\
\hline
\end{tabular}

\subsubsection{Grain Yield and Weight of 100 Grain}

Results (Table 3) showed that grain yield of wheat, upon addition of B at a level of $0.5 \mathrm{mg}$ per $\mathrm{Kg}$ soil, increased by $87.1 \%, 82 \%$ and $48 \%$ over that of no Boron addition to clay, loam and sandy loam soil, respectively. High response to $\mathrm{B}$ addition in clay textured soil may be attributed to adequate levels of plant essential nutrients (Table 1) and the possibility that B is the main constrain for plant growth in such soil, which is in agreement with the report of (Shorrocks, 1997). Least response in grain yield was observed in sandy loam soil which may be explained on the basis that this soil is of low level of plant essential nutrients (Table 1). This may be coincided with previous reports that low level of other essential nutrients are main constrain for plant growth in light textured soils (Niaz et al., 2007; Rashid et al., 2005; Johnson et al., 2005; Zia et al., 2006). Weight of 100 grain per pot as an important growth bio indicator (Shafig, 2008) showed that weight of 100 grain per pot with and without B addition was significantly the highest under the clay textured soil and was the significantly least under the loam textured soil which is in agreement with plant essential nutrient of the two soils. This may clearly indicate that other plant growth limiting factor other than B is prevailing in such soils (Niaz et al., 2002; Niaz et al., 2007).

Table 3. Effect of B application on grain yield and on the weight of 100 grain

\begin{tabular}{|c|c|c|c|c|c|c|c|c|}
\hline \multirow{2}{*}{$\begin{array}{l}\text { Boron Application } \\
\text { level } \mathrm{mg} \mathrm{kg}^{-1} \text { soil }\end{array}$} & \multicolumn{2}{|c|}{ Clay soil } & \multicolumn{2}{|c|}{ Loam soil } & \multicolumn{2}{|c|}{ Sandy loamy soil } & \multicolumn{2}{|c|}{ Mean $\left(\mathrm{X}^{-}\right)$} \\
\hline & $\begin{array}{l}\text { Grin yield } \\
\text { gm pot }^{-1}\end{array}$ & $\begin{array}{l}\text { Wight } 100 \\
\text { grain gm }\end{array}$ & $\begin{array}{l}\text { Grin yield } \\
\text { gm pots }^{-1}\end{array}$ & $\begin{array}{l}\text { Wight } 100 \\
\text { grain gm }\end{array}$ & $\begin{array}{l}\text { Grin yield } \\
\text { gm pots }^{-1}\end{array}$ & $\begin{array}{l}\text { Wight } 100 \\
\text { grain gm }\end{array}$ & $\begin{array}{l}\text { Grin yield } \\
\text { gm pots }^{-1}\end{array}$ & $\begin{array}{l}\text { Wight } 100 \\
\text { grain gm }\end{array}$ \\
\hline 0.0 & 7.50 & 5.08 & 5.17 & 3.80 & 4.57 & 3.43 & 5.75 & 4.10 \\
\hline 0.5 & 14.03 & 5.40 & 9.40 & 5.09 & 6.78 & 4.13 & 10.10 & 4.87 \\
\hline $\operatorname{Mean}\left(\mathrm{X}^{-}\right)$ & 10.77 & 5.24 & 7.28 & 4.44 & 5.68 & 3.78 & 7.92 & 4.48 \\
\hline \multirow{2}{*}{ Variable } & & & \multicolumn{6}{|c|}{ Least Significant Difference LSD } \\
\hline & & & \multicolumn{2}{|c|}{ Green yield gm pot ${ }^{-1}$} & & \multicolumn{2}{|c|}{ Wight 100 grain gm } & \\
\hline Application level & & & 0.827 & & & 0.491 & & \\
\hline Soil & & & 1.013 & & & 0.601 & & \\
\hline Interaction & & & 0.85 & & & 1.432 & & \\
\hline
\end{tabular}

\subsection{B Concentration and Uptake in Straw and Grain}

Application of B to soils at $0.5 \mathrm{mg}$ B per kg soil showed (Table 4) a significant increase of B concentration in straw. It was increased by $31.5 \%$ over that without $\mathrm{B}$ addition as an average over the three soils used. The increase of B content in straw with addition of B confirm the positive wheat response to added B which may be supported by the finding of Singh and Singh (1984) which were confirmed by a number of researchers (Furlani 
et al., 2003; Johnson et al., 2005; Tsadilas et al., 2005; Shafig, 2008), also, addition of B to soils increased B uptake by straw by $77 \%, 81 \%$ and $184 \%$ compared to those of zero B addition to clay soil, loam soil and sandy loam soil, respectively. These results were in agreement with those of Shafig (2008).

Table 4. Effect of B on its concentration and uptake in straw

\begin{tabular}{|c|c|c|c|c|c|c|c|c|}
\hline \multirow{2}{*}{$\begin{array}{l}\text { B Application } \\
\text { level } \mathrm{mg} \mathrm{Kg}^{-1}\end{array}$} & \multicolumn{2}{|c|}{ Clay soil } & \multicolumn{2}{|c|}{ Loam soil } & \multicolumn{2}{|c|}{ Sandy loam soil } & \multicolumn{2}{|c|}{$\operatorname{Mean}\left(\mathrm{X}^{-}\right)$} \\
\hline & $\begin{array}{l}\text { B concentration } \\
\mathrm{mg} \mathrm{Kg}^{-1}\end{array}$ & $\begin{array}{l}\text { B uptake } \\
\mu g \text { pot }^{-1}\end{array}$ & $\begin{array}{l}\text { B concentration } \\
\mathrm{mg} \mathrm{Kg}^{-1}\end{array}$ & $\begin{array}{l}\text { B uptake } \\
\mu \text { g pot }^{-1}\end{array}$ & $\begin{array}{l}\text { B concentration } \\
\mathrm{mg} \mathrm{Kg}^{-1}\end{array}$ & $\begin{array}{l}\text { B uptake } \\
\mu \mathrm{g} \operatorname{pot}^{-1}\end{array}$ & $\begin{array}{l}\text { B concentration } \\
\mathrm{mg} \mathrm{Kg}^{-1}\end{array}$ & $\begin{array}{l}\text { B uptake } \\
\mu \mathrm{g} \mathrm{pot}^{-1}\end{array}$ \\
\hline 0.0 & 18.000 & 378.0 & 18.817 & 364.13 & 15.117 & 213.08 & 17.311 & 318.403 \\
\hline 0.5 & 19.087 & 670.526 & 27.417 & 659.93 & 26.267 & 605.48 & 24.257 & 645.312 \\
\hline Mean $\left(\mathrm{X}^{-}\right)$ & 18.544 & 524.263 & 23.117 & 512.03 & 20.692 & 409.28 & 20.784 & 481.858 \\
\hline \multirow{2}{*}{\multicolumn{3}{|c|}{ Variable }} & \multicolumn{6}{|c|}{ Least Significant Difference LSD } \\
\hline & & & \multicolumn{3}{|c|}{ B concentration $\mathrm{mg} \mathrm{Kg}^{-1}$} & \multicolumn{3}{|c|}{ B uptake $\mu \mathrm{g} \mathrm{pot}^{-1}$} \\
\hline \multicolumn{3}{|c|}{ Application level } & \multicolumn{3}{|l|}{1.6027} & \multicolumn{3}{|l|}{48.262} \\
\hline \multicolumn{3}{|l|}{ Soil } & \multicolumn{3}{|l|}{1.9629} & \multicolumn{3}{|l|}{59.109} \\
\hline \multicolumn{3}{|l|}{ Interaction } & \multicolumn{3}{|l|}{2.776} & \multicolumn{3}{|l|}{83.593} \\
\hline
\end{tabular}

Application of B to soils at $0.5 \mathrm{mg} \mathrm{B}$ per kg soil showed (Table 5) a significant increase of B concentration in wheat grains. It was increased by $40 \%$ over that without $\mathrm{B}$ addition as an average over the three soils used. The increase of B content in grain with addition of B confirm the positive wheat response to add B which may be supported by the finding of V. Singh and S. P. Singh (1984) which were confirmed by a number of researchers (Furlani et al., 2003; Johnson et al., 2005; Tsadilas et al., 2005; Shafig, 2008).

Furthermore, Addition of B to soils increased B uptake by wheat by $121 \%, 157 \%$ and $96.9 \%$ compared to those of zero B addition to clay soil, loam soil and sandy loamy soil, respectively. These results were in agreement with those of Shafig (2008).

Table 5. Effect of B on its concentration and uptake in grain

\begin{tabular}{|c|c|c|c|c|c|c|c|c|}
\hline \multirow{2}{*}{$\begin{array}{l}\text { B Application } \\
\text { level } \mathrm{mg} \mathrm{Kg}^{-1}\end{array}$} & \multicolumn{2}{|c|}{ Clay soil } & \multicolumn{2}{|c|}{ Loam soil } & \multicolumn{2}{|c|}{ Sandy loam soil } & \multicolumn{2}{|c|}{ Mean (X-) } \\
\hline & $\begin{array}{l}\text { B concentration } \\
\mathrm{mg} \mathrm{Kg}^{-1}\end{array}$ & $\begin{array}{l}\text { B uptake } \\
\mu \text { g pot }^{-1}\end{array}$ & $\begin{array}{l}\text { B concentration } \\
\mathrm{mg} \mathrm{Kg}^{-1}\end{array}$ & $\begin{array}{l}\text { B uptake } \\
\mu \text { g pot }^{-1}\end{array}$ & $\begin{array}{l}\text { B concentration } \\
\mathrm{mg} \mathrm{Kg}^{-1}\end{array}$ & $\begin{array}{l}\text { B uptake } \\
\mu \mathrm{g} \mathrm{pot}^{-1}\end{array}$ & $\begin{array}{l}\text { B concentration } \\
\mathrm{mg} \mathrm{Kg}^{-1}\end{array}$ & $\begin{array}{l}\text { B uptake } \\
\mu \mathrm{g} \operatorname{pot}^{-1}\end{array}$ \\
\hline 0.0 & 12.8 & 96.0 & 15.2 & 78.6 & 0.284 & 1.30 & 9.43 & 58.6 \\
\hline 0.5 & 15.2 & 212 & 21.5 & 202 & 0.377 & 2.56 & 12.4 & 139 \\
\hline Mean (X-) & 14.0 & 154 & 18.4 & 140 & 0.331 & 1.93 & 10.9 & 98.9 \\
\hline \multirow{2}{*}{\multicolumn{3}{|c|}{ Variable }} & \multicolumn{6}{|c|}{ Least Significant Difference LSD } \\
\hline & & & \multicolumn{3}{|c|}{ B concentration $\mathrm{mg} \mathrm{Kg}^{-1}$} & \multicolumn{3}{|c|}{ B uptake $\mu$ g pot $^{-1}$} \\
\hline \multicolumn{3}{|c|}{ Application level } & \multicolumn{3}{|l|}{0.973} & \multicolumn{3}{|l|}{12.1} \\
\hline \multicolumn{3}{|l|}{ Soil } & \multicolumn{3}{|l|}{1.192} & \multicolumn{3}{|l|}{14.9} \\
\hline \multicolumn{3}{|l|}{ Interaction } & \multicolumn{3}{|l|}{1.686} & \multicolumn{3}{|l|}{21.0} \\
\hline
\end{tabular}

The results of this study also showed that the interaction between B application and soil type had a significant effect at the level of $\mathrm{P} \leq 0.05$ on $\mathrm{B}$ uptake by plant (Tables 4 and 5). B uptake as an average over three soils received $\mathrm{B}$ addition 102.7 and $137 \%$ higher than that of zero B addition in straw and grain respectively. It is noted that response to B fertilizer increased significantly in all soils due to increase of available B content in soils upon B addition.

\section{Conclusion}

Boron (B) is non-metal essential microelement for plants and it is needed for normal plant growth and development. Boron deficiency under arid condition is very common especially under intensive cropping system. $\mathrm{B}$ application at an adequate level to soils of arid regions need to be adapted as a part of successful fertilizer recommendation. Further studies to determine the major crops response curve to B addition is very much essential to develop effective package of B application for obtaining expected yield. 


\section{Reference}

Ahmad, W., Niaz, A., Kanwal, S., Rahmatullah, \& Rasheed, M. K. (2009). Role of boron in plant growth: A review. Journal of Agricultural Research, 47, 329-338.

Barber, S. A. (1995). Soil nutrient bioavailability: A mechanistic approach. John Wiley and Sons, New York, NY, USA.

Bassil, E., Hu, H., \& Brown, P. H. (2004). Use of phenylboronic acids to investigate boron function in plants. Possible role of boron in transvacuolar cytoplasmic strands and cell-to-wall adhesion. Plant Physiol., 136, 3383-3395. https://doi.org/10.1104/pp.104.040527

Borkakati, K., \& Takkar, P. N. (2000). Forms of boron in acid alluvial and lateritic soils in relation to ecosystem and rainfall distribution. Proceedings of International Conference on Managing Resources for Sustainable Agricultural Production in the $21^{\text {st }}$ Century. Better Crops, 2, 127-128.

Brown, P. H., Bellaloui, N., Wimmer, M. A., Bassil, E. S., Ruiz, J., Hu, H., ... Römheld, V. (2002). Boron in plant biology. Plant Biol., 4, 205-23. https://doi.org/10.1055/s-2002-25740

Chang, S. S. (1993). Nutritional physiology of boron and the diagnosis and correction of boron deficiency and toxicity in crops. In S. N. Hwang, \& G. C. Chiang (Eds.), Proceedings of the Symposium on Reclamation of the Problem Soils in the Eastern Taiwan (pp. 109-122). Chinese Society of Plant Nutrition and Fertilizer Science and Hwalian District Agricultural Improvement Station, Taiwan.

De Oliveira, R. H., Milanez, C. R. D., Moraes-Dallaqua, M. A., \& Rosolem, C. A. (2006). Boron deficiency inhibits petiole and peduncle cell development and reduces growth of cotton. Journal of Plant Nutrition, 29, 2035-2048. https://doi.org/10.1080/01904160600932617

Diana, G. (2006). Boron in the soil, from deficit to toxicity. Informatore Agrario, 62, 54-58.

Elrashidi, M. A., \& O'Connor, G. A. (1982). Boron sorption and desorption in soils. Soil Sci. Soc. Am. J., 46, 1127- 1131. https://doi.org/10.2136/sssaj1982.03615995004600010005x

Furlani, A. M. C., Carvalho, C. P., Freitas, de J. G., \& Verdial, M. F. (2003). Wheat cultivar tolerance to boron deficiency and toxicity in nutrient solution. Scientia-Agricola, 60(2), 359-370. https://doi.org/10.1590/ S0103-90162003000200022

Goldberg, S. (1997). Reaction of boron with soils. Plant and Soil, 193, 35- 48. https://doi.org/10.1023/A:10042 03723343

Gupta, U., \& Solanki, H. (2013). Impact of boron deficiency on plant growth. International Journal of Bioassays, 1048-1050.

Hajiboland, R., \& Farhanghi, F. (2011). Effect of low boron supply in turnip plants under drought stress. Biologia Plantarum, 55(4), 775-778. https://doi.org/10.1007/s10535-011-0186-4

Huang, L., Pant, J., Dell, B., \& Bell, R. (2000). Effects of boron deficiency on anther development and floret sterility in wheat (Triticum aestivum L. 'Wilgoyne'). Ann. Bot., 85, 493-500. https://doi.org/10.1006/anbo. 1999.1095

Johnson, S. E., Lauren, J. G., Welch, R. M., \& Duxbury, J. M. (2005). A comparison of the effects of micronutrient seed priming and soil fertilization on the mineral nutrition of chickpea (Cicer arietinum), lentil (Lens culinaris), rice (Oryza sativa) and wheat (Triticum aestivum) in Nepal. Experimental Agriculture, 41(4), 427-448. https://doi.org/10.1017/S0014479705002851

Malhi, S. S., Raza, M., Schoenau, J. J., Mermut, A. R., Kutcher, R., Johnston, A. M., \& Gill, K. S. (2003). Feasibility of B fertilization for yield, seed quality, and B uptake of canola in north eastern Saskatchewan. Canadian Journal of Soil Science, 83, 99-108. https://doi.org/10.4141/S01-081

Muntean, D. W. (2009). Boron, the overlooked essential element. Soil and Plant Laboratory Inc., Bellevue, WA.

Niaz, A., Ibrahim, M., Nisar, A., \& Anwar, S. A. (2002). Boron contents of light and medium textured soils and cotton plants. International Journal of Agriculture and Biology, 4, 534-536.

Niaz, A., Ranjha, A. M., Rahmatullah, Hannan, A., \& Waqas, M. (2007). Boron status of soils as affected by different soil characteristics-pH, $\mathrm{CaCO}_{3}$, organic matter and clay contents. Pakistan Journal of Agricultural Sciences, 44, 428-435.

Page, A. L., Miller,R. H., \& Kenney, D. R.(1982). Methods of soil analysis. Part 2. Chemical and Microbiological Properties. Am. Soc. Agron. Madison, Wis. 
Rashid, A. (2006). Boron deficiency in soils and crops of Pakistan: Diagnosis and management (Vol. iii, p. 34). Pakistan Agricultural Research Council (PARC), Islamabad, Pakistan.

Rashid, A., Muhammad, S., \& Rafique, E. (2005). Rice and wheat genotypic variation in boron use efficiency. Soil Environ., 24, 98-102.

Raza, M., Mermut, A. R., Schoenau, J. J., \& Malhi, S. S. (2002). Boron fractionation in some Saskatchewan soils. Canadian Journal of Soil Science, 82, 173-179. https://doi.org/10.4141/S01-027

Shafiq, M. (2008). Estimation of boron requirement of rice and wheat crops using adsorption isotherm technique (PhD. thesis, University of Agriculture, Faisalabad).

Shorrocks, V. M. (1997). The occurrence and correction of boron deficiency. Plant and Soil, 193, $121-148$. https://doi.org/10.1023/A:1004216126069

Singh, V., \& Singh, S. P. (1984). Effect of applied boron on nutrients and uptake by barley crop. Curr. Agric., 8 , 86-90.

Sinha, R. B., Sakal, R., Singh, A. P., \& Bhogal, N. S. (1991). Response of some field crops to boron application in calcareous soils. Journal of Indian Society of Soil Science, 39, 342-345.

Soil Survey Staff(SSS). (1975). Soil Taxonomy: A Basic System of Soil Classification for Making and Interpreting Soil Surveys. Soil Conservation Service, USDA, Washinghton, D.C.

Tsadilas, C. D., Argyropoulos, G., \& Tsadila, E. (2005). Estimation of External Boron Requirements and Their Correlation to Soil Prperties in Red Mediterranean Soils. The 3rd International Symposium on All Aspects of Plant and Animal Boron Nutrition, September 9-13, 2005, Huazhong Agricultural University Wuhan, China.

Zia, M. H., Ahmad, R., Khaliq, I., Ahmad, A., \& Irshad, M. (2006). Micronutrients status and management in orchards soils: Applied aspects. Soil \& Environment, 25, 616.

\section{Copyrights}

Copyright for this article is retained by the author(s), with first publication rights granted to the journal.

This is an open-access article distributed under the terms and conditions of the Creative Commons Attribution license (http://creativecommons.org/licenses/by/4.0/). 